\title{
Japanese Brome Response to Atrazine in Com- bination with Nitrogen Fertilizer in the Mixed Prairie
}

\author{
D.B. HEWLETT, J.R. JOHNSON, R.I. BUTTERFIELD, AND \\ V.K. MOSLEY
}

\begin{abstract}
Atrazine was used to control Japanese brome in conjunction with nitrogen fertilization to determine if herbage production could be increased more than by fertilization alone. Atrazine treatments included a single application, application in alternate years, and application for two or three consecutive years. Atrazine did not significantly increase production more than fertilizer alone and caused some decreases in western wheatgrass production at low rates of $\mathbf{N}$ in one year at one location. Unless atrazine was applied in two or more years, Japanese brome was a prevalent the second growing season after application as where it had never been controlled. Application of atrazine in consecutive years increased shortgrass production at one location.
\end{abstract}

Japanese brome (Bromus japonicus) is an introduced annual from Eurasia. A winter annual, it is similar to downy brome ( $B$. tectorum) but becomes more abundant than downy brome as soil moisture supplies increase (Hulbert 1955). Both species occur in South Dakota, but Japanese brome is more abundant on rangeland. Japanese brome is a newcomer to parts of South Dakota. In western South Dakota, Lewis et al. (1975) observed Japanese brome in one small area of their research pastures in 1951. By 1955 the invading grass was a major component of this rangeland. Since then the abundance of Japanese brome has been highly variable, depending on favorable fall moisture.

Atrazine [2-chloro-4-(ethylamino)-6-(isopropylamino)-strazine] has been demonstrated to be effective in controlling annual bromes (Arnold and O’Neal 1972; Morrow et al. 1977). Nitrogen $(\mathrm{N})$ fertilization is widely known to increase the production of cool-season species. Several studies have combined application of atrazine with $\mathbf{N}$ fertilization on rangeland for various reasons. Houston and van der Sluijs $(1973 ; 1975)$ have shown that atrazine and nitrogen stimulated protein production on shortgrass ranges. Hyder et al. (1976) investigated the drought resistance of blue grama (Bouteloua gracilis) as affected by atrazine and nitrogen fertilizer. Nitrogen fertilization plus atrazine used to control downy brome invasion increased the 4-year average yields of Greenar intermediate wheatgrass (Agropyron intermedium) $100 \%$ over fertilization alone (Kay 1971).

It was felt that control of Japanese brome in conjunction with $\mathbf{N}$ fertilization might result in increases in yields of western wheatgrass (A. smithii). The objectives of this experiment were: (1) to determine if western wheatgrass production could be increased by controlling Japanese brome with atrazine; (2) to determine if atrazine control of Japanese brome in combinatıon with nitrogen

Authors are, respectively, assistant in plant science, extension range specialist, assistant in animal science, and former assistant in plant science, South Dakota State University, West River Research and Extension Center, 801 San Francisco St., Rapid City, 57701 .

R.G. Hoeft and W.E. Arnold are gratefully acknowledged for design and initiation of the project. The research was funded in part by the Farmers Union Central Exchange Foundation.

This paper was published with the approval of the Director, South Dakota Agricultural Experiment Station, as Journal No. 1627.

Manuscript received April 30, 1979.
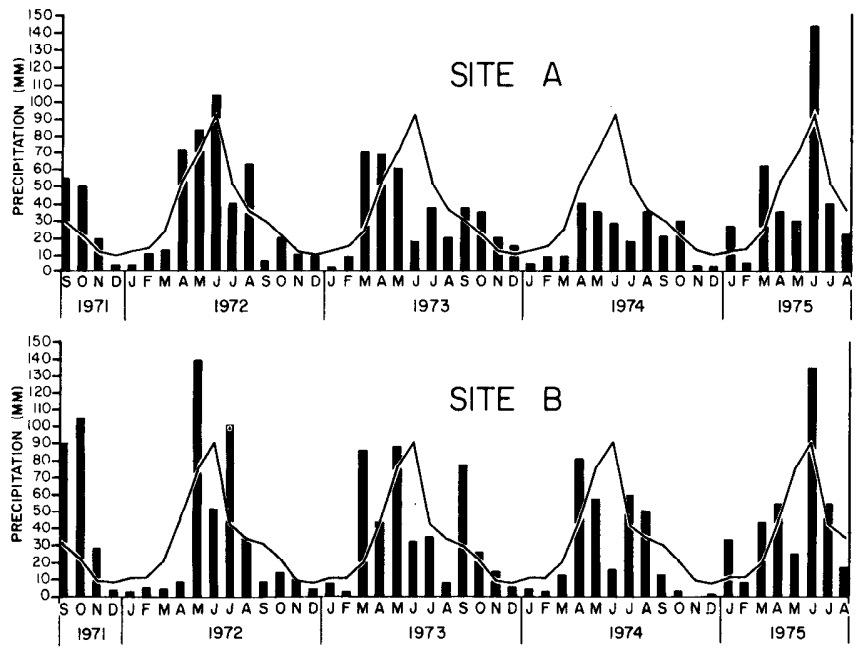

Fig. 1. Actual (bars) and long-term (solid lines) monthly precipitation $(\mathrm{mm})$ at the study sites.

fertilizaton would increase herbage production more than fertilization alone; and (3) to determine the effects of repeated applications of atrazine on other components of the vegetation.

\section{Study Area and Methods}

This study was conducted on two Clayey range sites (U.S.D.A. 1977) in western South Dakota. Site A, located near Rapid City, was in excellent range condition in 1973 and Site B near Cottonwood was in good range condition, following procedures of Dyksterhuis (1949). Major species of the study sites were western wheatgrass, blue grama, and buffalograss (Buchloe dactyloides). Forbs were a very minor component, contributing less than 5 percent of the total production. Both sites had approximately equal proportions of western wheatgrass and shortgrass (blue grama and buffalograss), while Site B had a much higher proportion of Japanese brome, which accounted for the lower range condition. Figure 1 shows monthly and yearly (September through August) precipitation for weather stations located $1.2 \mathrm{~km}$ northwest of Site A and $4.2 \mathrm{~km}$ southeast of Site B. Long-term normal precipitation is $435 \mathrm{~mm}$ (17.12 in) for Site $A$ and $408 \mathrm{~mm}$ (16.06 in) for Site $B$, with the major portion falling as rain during spring and early summer.

A split-plot design was used with two replications. ${ }^{1}$ Herbicide treatments were assigned to whole plots and fertility treatment to subplots. Atrazine was applied prior to the 1973, 1974, and 1975 growing seasons. Atrazine treatments resulting after 3 years were:

1) Control, no atrazine applied.

2) Atrazine applied in only one year (1973).

'The study was originally designed with four replications. However, after initiation it was decided to reapply herbicide. Two replications were eliminated to allow enough space for the additional herbicide splits, each containing the same fertility treatments. 
Table 1. Interaction means for 1974 western wheatgrass dry matter production $(\mathrm{kg} / \mathrm{ha})$ at site $\mathrm{A.} .^{1}$

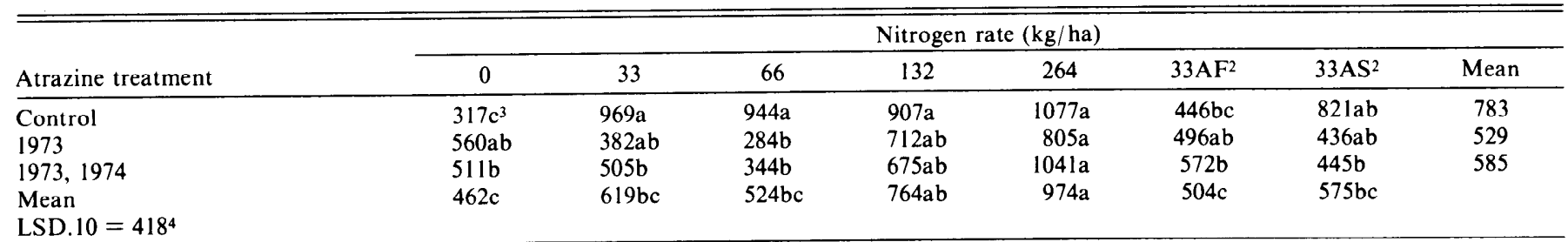

The atrazine-nitrogen treatment interaction was significant at the $10 \%$ level.

${ }^{2} \mathrm{AF}$ and $\mathrm{AS}$ designate annual fall and spring application, respectively.

${ }^{3}$ Numbers in the same row followed by the same letter do not differ significantly at the $5 \%$ level by Duncan's multiple range test.

${ }^{4}$ For atrazine treatments within a single rate of nitrogen (column).

3) Atrazine applied in two consecutive years (1973, 1974).

4) Atrazine applied in alternate years (1973, 1975).

5) Atrazine applied in three consecutive years (1973, 1974, 1975).

Years, as discussed here, refer to growing seasons in which the herbage was sampled, rather than the time of herbicide application. Atrazine, at the rate of $1.1 \mathrm{~kg} / \mathrm{ha}(1 \mathrm{lb} /$ acre $)$ in water with crop oil, was applied with a ground sprayer in the fall prior to the growing season, except for 1975 when circumstances dictated a spring application.

Subplots in each of the atrazine treatments received one application of ammonium nitrate in the fall of 1972 . Rates were $0,33,66$, 132 , and $264 \mathrm{~kg} \mathrm{~N} /$ ha $(0,30,60,120$, and $240 \mathrm{lb} \mathrm{N} /$ acre $)$. In addition, $33 \mathrm{~kg} \mathrm{~N} /$ ha were applied annually each spring and fall as two separate treatments for a total of seven fertility treatments within each herbicide treatment.

Each year a $61 \mathrm{~cm} \times 146 \mathrm{~cm}\left(2^{\prime} \times 4.8^{\prime}\right)$ plot was clipped to ground level, sorted, and oven dried to determine herbage production for each treatment. Species categories were western wheatgrass, Japanese brome, short grasses (blue grama, buffalograss), forbs, and other (perennial grasses and sedges). A standard analysis of variance for a split-plot design (Steele and Torrie 1960) was performed for species components within each year, with the exception of the category designated as "other."

\section{Results and Discussion}

Nitrogen fertilization of rangeland in western South Dakota to increase cool-season perennial grasses has often produced dramatic increases in Japanese brome. Removal with atrazine of annual brome competition in conjunction with $\mathrm{N}$ fertilization was expected to result in an increased response of western wheatgrass to the $\mathrm{N}$. This type of interaction was not observed. An interaction was detected for western wheatgrass at Site A in 1974 (Table 1). In this instance, both the single application of atrazine in 1973 and two consecutive years of atrazine $(1973,1974)$ decreased 1974 western wheatgrass production at the lower levels of $\mathrm{N}(33,66$ $\mathrm{kg} / \mathrm{ha}$ ), but not for the other $\mathrm{N}$ treatments. The use of atrazine to control Japanese brome did not increase the response of western wheatgrass production to $\mathrm{N}$ but actually caused decreases, which were overcome by higher rates of $\mathrm{N}$. Other researchers (Houston 1977; Houston and van der Sluijs 1975; Morrow et al. 1977) have also reported that atrazine was detrimental to cool-season grasses. A significant atrazine $\times N$ interaction was also observed for Japanese brome. This resulted because Japanese brome generally responded to $\mathrm{N}$ where the species was not controlled but could not respond where it had been removed by atrazine. Because these were the only significant interactions, the differences discussed in the rest of this paper refer to overall means for either atrazine or fertility treatments, except for Japanese brome responses to $\mathrm{N}$.

Atrazine decreased the production of Japanese brome during the growing season following application (Table 2). However, in 1974 and 1975 where atrazine was not reapplied the second or third year, Japanese brome production increased to the level of the control (Fig. 2). In 1975, the plots receiving two consecutive applications of atrazine $(1973,1974)$ but no atrazine in 1975 , had significantly less Japanese brome than the control and nor more than those plots treated for three consecutive years $(1973,1974$, 1975).

Table 2. 1973-75 dry matter production (kg/ha) by species at two study sites for 5 atrazine treatments over all fertility levels.

\begin{tabular}{|c|c|c|c|c|c|c|c|c|c|c|c|}
\hline \multirow[b]{3}{*}{ Species } & \multirow[b]{3}{*}{ Year } & \multicolumn{10}{|c|}{ Growing season for which atrazine was applied } \\
\hline & & \multicolumn{5}{|c|}{ Site A } & \multicolumn{5}{|c|}{ Site B } \\
\hline & & Control & 1973 & 1973,74 & 1973,75 & $1973,74,7$ & 5 Control & 1973 & 1973,74 & 1973,75 & $1973,74,75$ \\
\hline Western wheatgrass & $\begin{array}{l}1973 \\
1974 \\
1975\end{array}$ & $\begin{array}{c}1318 a^{2} \\
783 a \\
1968 a\end{array}$ & $\begin{array}{r}1074 a \\
529 a \\
1754 a\end{array}$ & $\begin{array}{r}585 a \\
2346 a\end{array}$ & $1927 a$ & $1678 \mathbf{a}$ & $\begin{array}{r}855 a \\
513 a \\
1336 a\end{array}$ & $\begin{array}{l}825 a \\
440 a \\
71.8 a\end{array}$ & $\begin{array}{l}747 a \\
718 a\end{array}$ & $690 \mathrm{a}$ & $627 a$ \\
\hline Japanese brome & $\begin{array}{l}1973 \\
1974 \\
1975\end{array}$ & $\begin{array}{l}148 \mathrm{a} \\
317 \mathrm{a} \\
317 \mathrm{~b}\end{array}$ & $\begin{array}{r}16 a \\
417 a \\
579 a\end{array}$ & $\begin{array}{l}10 b \\
34 c\end{array}$ & $220 \mathrm{bc}$ & $5 c$ & $\begin{array}{l}718 a \\
949 a \\
262 a\end{array}$ & $\begin{array}{r}0 \mathrm{~b} \\
972 \mathrm{a} \\
339 \mathrm{a}\end{array}$ & $\begin{array}{l}<1 \mathrm{~b} \\
10 \mathrm{~b}\end{array}$ & $25 \mathrm{~b}$ & $<\mathrm{lb}$ \\
\hline Shortgrasses & $\begin{array}{l}1973 \\
1974 \\
1975\end{array}$ & $\begin{array}{l}263 \mathrm{a} \\
128 \mathrm{~b} \\
303 \mathrm{c}\end{array}$ & $\begin{array}{l}512 \mathrm{a} \\
195 \mathrm{~b} \\
295 \mathrm{c}\end{array}$ & $\begin{array}{l}455 \mathrm{a} \\
568 \mathrm{ab}\end{array}$ & $405 \mathrm{bc}$ & $751 \mathrm{a}$ & $\begin{array}{l}300 \mathrm{~b} \\
149 \mathrm{a} \\
361 \mathrm{a}\end{array}$ & $\begin{array}{l}678 a \\
488 a \\
867 a\end{array}$ & $\begin{array}{r}670 \mathrm{a} \\
1225 \mathrm{a}\end{array}$ & 1088a & $1124 a$ \\
\hline Totall & $\begin{array}{l}1973 \\
1974 \\
1975\end{array}$ & $\begin{array}{l}2048 a \\
1297 a \\
2797 a\end{array}$ & $\begin{array}{l}1756 a \\
1183 a b \\
2747 a\end{array}$ & $\begin{array}{l}1087 \mathrm{~b} \\
3052 \mathrm{a}\end{array}$ & $2717 a$ & 2621a & $\begin{array}{l}1903 a \\
1613 a \\
2050 a\end{array}$ & $\begin{array}{l}1528 \mathrm{a} \\
1914 \mathrm{a} \\
1996 \mathrm{a}\end{array}$ & $\begin{array}{l}1454 a \\
2019 a\end{array}$ & 1836a & $1844 a$ \\
\hline $\begin{array}{l}\text { Total } \\
\text { minus } \\
\text { Japanese brome }\end{array}$ & $\begin{array}{l}1973 \\
1974 \\
1975\end{array}$ & $\begin{array}{r}1900 \mathrm{a} \\
982 \mathrm{a} \\
2440 \mathrm{a}\end{array}$ & $\begin{array}{r}1741 a \\
766 a \\
2161 a\end{array}$ & $\begin{array}{l}1074 a \\
3018 a\end{array}$ & $2488 \mathrm{a}$ & $2705 a$ & $\begin{array}{r}1105 \mathrm{a} \\
644 \mathrm{~b} \\
1751 \mathrm{a}\end{array}$ & $\begin{array}{l}1529 \mathrm{a} \\
932 \mathrm{ab} \\
1624 \mathrm{a}\end{array}$ & $\begin{array}{l}1428 a \\
1969 a\end{array}$ & $1800 \mathrm{a}$ & $1805 \mathrm{a}$ \\
\hline
\end{tabular}

IMay include a minor amount of other perennial grasses, forbs and sedges in addition to components listed.

${ }^{2}$ Means in the same row for a particular site and species followed by the same letter do not differ significantly at the $5 \%$ level by Duncan's multiple range test. 
Table 3. 1973-75 dry matter production (kg/ha) by species at two study sites for 7 rates of nitrogen'.

\begin{tabular}{|c|c|c|c|c|c|c|c|c|c|c|c|c|c|c|c|}
\hline \multirow[b]{3}{*}{ Species } & \multirow[b]{3}{*}{ Year } & \multicolumn{14}{|c|}{ Rates of nitrogen $(\mathrm{kg} / \mathrm{ha})$} \\
\hline & & \multicolumn{7}{|c|}{ Site A } & \multicolumn{7}{|c|}{ Site B } \\
\hline & & 0 & 33 & 66 & 132 & 264 & $33 \mathrm{AF}^{3}$ & $33 \mathrm{AS}^{3}$ & 0 & 33 & 66 & 132 & 264 & $33 \mathrm{AF}^{3}$ & $33 \mathrm{AS}^{3}$ \\
\hline $\begin{array}{l}\text { Western } \\
\text { wheatgrass }\end{array}$ & $\begin{array}{l}1973 \\
1974 \\
1975^{4}\end{array}$ & $\begin{array}{r}757 b^{5} \\
462 c \\
991 d\end{array}$ & $\begin{array}{l}901 \mathrm{~b} \\
619 \mathrm{bc}\end{array}$ & $\begin{array}{l}1084 \mathrm{~b} \\
524 \mathrm{bc}\end{array}$ & $\begin{array}{r}1565 \mathrm{ab} \\
764 \mathrm{ab} \\
2536 \mathrm{ab}\end{array}$ & $\begin{array}{r}2187 a \\
974 a \\
2894 a\end{array}$ & $\begin{array}{c}1007 b \\
504 c \\
1927 b c\end{array}$ & $\begin{array}{c}868 \mathrm{~b} \\
575 \mathrm{bc} \\
1360 \mathrm{~cd}\end{array}$ & $\begin{array}{l}535 a \\
351 c \\
436 b\end{array}$ & $\begin{array}{l}871 \mathrm{a} \\
388 \mathrm{bc}\end{array}$ & $\begin{array}{l}759 a \\
447 b c\end{array}$ & $\begin{array}{l}894 a \\
881 a \\
939 a\end{array}$ & $\begin{array}{l}1217 \mathrm{a} \\
665 \mathrm{abc} \\
960 \mathrm{a}\end{array}$ & $\begin{array}{c}714 a \\
678 a b \\
1048 a\end{array}$ & $\begin{array}{l}888 \mathrm{a} \\
555 \mathrm{bc} \\
707 \mathrm{ab}\end{array}$ \\
\hline Japanese brome & $\begin{array}{l}1973 \\
1974 \\
1975^{4}\end{array}$ & $\begin{array}{c}86 b \\
150 c \\
188 b\end{array}$ & $\begin{array}{r}74 b \\
128 c\end{array}$ & $\begin{array}{l}119 a b \\
171 c\end{array}$ & $\begin{array}{r}361 \mathrm{a} \\
252 \mathrm{c} \\
72 \mathrm{~b}\end{array}$ & $\begin{array}{l}270 \mathrm{ab} \\
492 \mathrm{~b} \\
216 \mathrm{~b}\end{array}$ & $\begin{array}{r}59 \mathrm{~b} \\
721 \mathrm{a} \\
899 \mathrm{a}\end{array}$ & $\begin{array}{c}54 b \\
273 c \\
192 b\end{array}$ & $\begin{array}{c}692 a b c \\
686 b c \\
99 c\end{array}$ & $\begin{array}{l}372 \mathrm{c} \\
485 \mathrm{c}\end{array}$ & $\begin{array}{l}639 \mathrm{bc} \\
750 \mathrm{bc}\end{array}$ & $\begin{array}{r}971 \mathrm{ab} \\
1005 \mathrm{ab} \\
155 \mathrm{bc}\end{array}$ & $\begin{array}{r}1243 a \\
1370 a \\
592 a\end{array}$ & $\begin{array}{c}770 \mathrm{abc} \\
1293 \mathrm{a} \\
182 \mathrm{bc}\end{array}$ & $\begin{array}{l}279 c \\
966 a b c \\
268 b\end{array}$ \\
\hline Shortgrasses & $\begin{array}{l}1973 \\
1974 \\
19754\end{array}$ & $\begin{array}{l}409 a \\
267 a \\
595 a b\end{array}$ & $\begin{array}{l}546 a \\
209 a\end{array}$ & $\begin{array}{l}281 \mathrm{a} \\
261 \mathrm{a}\end{array}$ & $\begin{array}{l}535 a \\
232 a \\
382 b c\end{array}$ & $\begin{array}{l}235 a \\
116 a \\
264 c\end{array}$ & $\begin{array}{l}543 a \\
445 a \\
622 a\end{array}$ & $\begin{array}{l}168 a \\
288 a \\
459 a b c\end{array}$ & $\begin{array}{l}300 a \\
365 a \\
911 a\end{array}$ & $\begin{array}{l}360 a \\
519 a\end{array}$ & $\begin{array}{l}535 \mathrm{a} \\
516 \mathrm{a}\end{array}$ & $\begin{array}{l}582 a \\
286 a \\
854 a\end{array}$ & $\begin{array}{l}518 a \\
488 a \\
883 a\end{array}$ & $\begin{array}{l}354 a \\
271 a \\
934 a\end{array}$ & $\begin{array}{r}497 a \\
604 a \\
1083 a\end{array}$ \\
\hline Total ${ }^{2}$ & $\begin{array}{l}1973 \\
1974 \\
1975^{4}\end{array}$ & $\begin{array}{r}1426 \mathrm{~b} \\
934 \mathrm{c} \\
1718 \mathrm{c}\end{array}$ & $\begin{array}{l}1533 b \\
1094 a b c\end{array}$ & $\begin{array}{l}1619 b \\
1052 b c\end{array}$ & $\begin{array}{l}3038 \mathrm{a} \\
1255 \mathrm{ab} \\
3276 \mathrm{ab}\end{array}$ & $\begin{array}{l}2791 a \\
1414 a \\
3547 a\end{array}$ & $\begin{array}{l}1692 \mathrm{~b} \\
1354 \mathrm{ab} \\
2933 \mathrm{ab}\end{array}$ & $\begin{array}{l}1217 b \\
1222 a b c \\
2462 b c\end{array}$ & $\begin{array}{l}1194 \mathrm{c} \\
1117 \mathrm{~d} \\
1460 \mathrm{~b}\end{array}$ & $\begin{array}{l}1438 \mathrm{c} \\
1407 \mathrm{~cd}\end{array}$ & $\begin{array}{l}1620 b c \\
1522 b c\end{array}$ & $\begin{array}{l}2010 \mathrm{ab} \\
1886 \mathrm{a} \\
1998 \mathrm{a}\end{array}$ & $\begin{array}{l}2420 a \\
2065 a \\
2125 a\end{array}$ & $\begin{array}{l}1514 b c \\
1791 a b \\
2169 a\end{array}$ & $\begin{array}{l}1533 a b \\
1833 a b \\
1995 a\end{array}$ \\
\hline $\begin{array}{l}\text { Total minus } \\
\text { Japanese brome }\end{array}$ & $\begin{array}{r}1973 \\
1974 \\
\text { 1e } 1975^{4}\end{array}$ & $\begin{array}{r}1381 \mathrm{~b} \\
791 \mathrm{a} \\
1968 \mathrm{c}\end{array}$ & $\begin{array}{r}1495 b \\
893 a\end{array}$ & $\begin{array}{r}1558 \mathrm{~b} \\
826 \mathrm{a}\end{array}$ & $\begin{array}{l}2856 a \\
1042 a \\
3103 a\end{array}$ & $\begin{array}{l}2648 a \\
1120 a \\
3316 a\end{array}$ & $\begin{array}{c}1657 \mathrm{~b} \\
962 \mathrm{a} \\
2642 \mathrm{ab}\end{array}$ & $\begin{array}{r}1149 \mathrm{~b} \\
945 \mathrm{a} \\
2051 \mathrm{bc}\end{array}$ & $\begin{array}{r}843 b \\
718 b \\
1395 b\end{array}$ & $\begin{array}{r}1247 a b \\
911 a b\end{array}$ & $\begin{array}{r}1296 \mathrm{ab} \\
967 \mathrm{ab}\end{array}$ & $\begin{array}{l}1519 a b \\
1169 a \\
1832 a\end{array}$ & $\begin{array}{c}1790 \mathrm{a} \\
1171 \mathrm{a} \\
.1876 \mathrm{a}\end{array}$ & $\begin{array}{l}1123 a b \\
959 a b \\
2041 a\end{array}$ & $\begin{array}{l}1403 \mathrm{ab} \\
1161 \mathrm{a} \\
1806 \mathrm{a}\end{array}$ \\
\hline
\end{tabular}

${ }_{1}^{1}$ Means presented here are over all atrazine treatments except for Japanese brome, where atrazine treatments were excluded from the means.

2 May include a minor amount of other perennial grasses and sedges in addition to components listed.

${ }^{3} \mathrm{AF}$ and $\mathrm{AS}$ designate annual fall and spring applications, respectively.

4The one time applications of 33 and $66 \mathrm{~kg} /$ ha $\mathrm{N}$ were not harvested in 1975.

sMeans in the same row for a particular site and species followed by the same letter do not differ significantly at the $5 \%$ level by Duncan's multiple range test.

By 1975 shortgrass production appeared to have been favored by atrazine application. Specifically, production was increased at Site A after two and three consecutive years of application. At Site B, shortgrasses tended to increase for all atrazine treatments. Hyder et al. (1976) found that atrazine "protected" blue grama from drought, presumably from cumulative effects of weed control and/or reduced transpiration, especially when nitrogen fertilizer caused increased drought severity in a shortgrass prairie. In our situation, western wheatgrass is the primary forage species and an increase in shortgrasses will actually decrease range condition.

Forbs were not affected by the atrazine treatments at either study site and are a minor component of this range site.

Total herbage production was not significantly affected by atrazine except for a decrease in 1974 at Site A following two consecutive years of atrazine treatment. Reduction of Japanese brome by the herbicide treatment would decrease total herbage production unless some other forage component increases. If a herbage component increases and offsets the loss of Japanese brome, the increase would not be reflected in an analysis of total herbage herbage production. For this reason, we also examined "total production minus Japanese brome" as a measure of the response of perennial herbage. This category only increased significantly in 1974 from atrazine applied in 1973 and 1974 at Site B. Japanese brome comprised $60 \%$ of the vegetation of the control in 1974 at Site B. This was the highest proportion of Japanese brome during the study period. Apparently, Japanese brome was not competing significantly with perennial forage species except at the high level of infestation at Site B in 1974. An alternative explanation may be that the herbicide in some way negated positive effects from the removal of Japanese brome at all except the highest level of infestation. Lower rates of atrazine $(.5 \mathrm{lb} /$ acre $)$ have been used to control annual bromes (Morrow et al. 1977) and may be less damaging to cool-season grasses than the higher rate used in this study.

Cool-season grasses are known to respond to $\mathrm{N}$ fertilization. In this study, higher rates of $\mathbf{N}$ generally increased production of western wheatgrass the most and had the longest carryover response (Table 3). The one-time application of 33 and $66 \mathrm{~N} /$ ha produced no significant differences in western wheatgrass during the first two years and thus was not sampled in 1975. In 1975, the two highest rates of $\mathrm{N}$ were still showing a significant carryover response. The annual fall application of $33 \mathrm{~kg} \mathrm{~N} / \mathrm{ha}$ was also higher than the control.

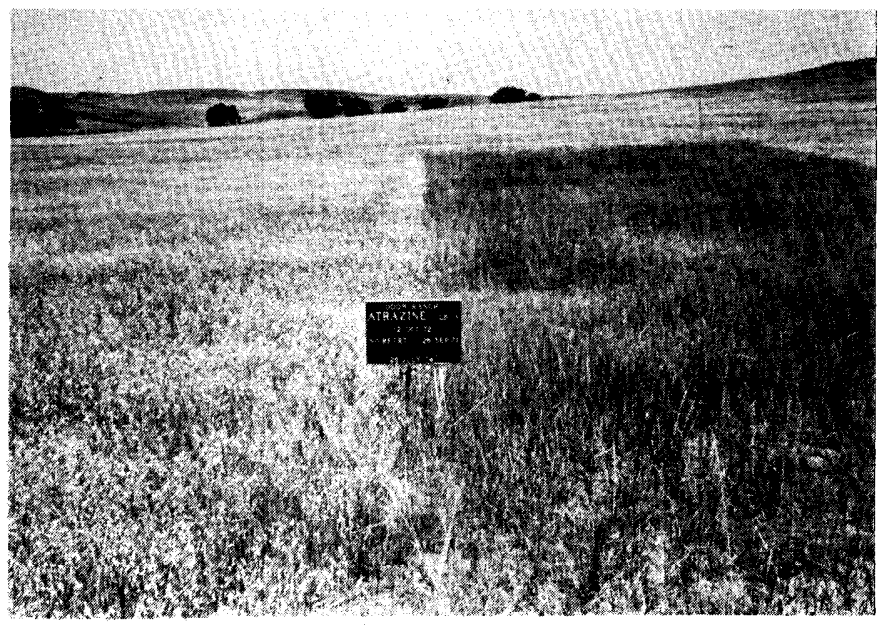

Fig. 2. Study Site B in 1974 showing high level of Japanese brome infestation on left and nearly complete absence on right. Atrazine was applied to both plots prior to the 1973 growing season, with reapplication on the right prior to 1974. On the left, Japanese brome production in 1974 equalled amounts from the untreated areas.

Japanese brome responded to $\mathrm{N}$ fertilization in all years. Higher rates generally gave largest responses. Carryover response to the highest rates of $\mathrm{N}$ was significant in 1975 at Site B but not at Site A. Responses to the annual spring and fall applications were inconsistent and could not be explained by precipitation patterns (Fig. 1).

The only significant response of shortgrasses to $\mathrm{N}$ fertilization was a decrease at high rates of $N$ at Site $A$ in 1975. Forbs demonstrated a significant increase in 1973 at Site $A$ from $132 \mathrm{~kg} \mathrm{~N} / \mathrm{ha}$, but in general no response was noted.

Total herbage production and "total minus Japanese brome" generally increased with higher rates of fertilizer. Carryover at the highest rates was still evident in 1975.

\section{Conclusions}

The use of atrazine to control Japanse brome did not benefit the 
major forage species, western wheatgrass. Nitrogen fertilizer alone increased western wheatgrass production as much as nitrogen in combination with atrazinc. Unless atrazine was applied in two consecutive years, Japanese brome was as abundant the year after treatment as where it had not been controlled. Atrazine increased the production of shortgrasses at one study site with a similar trend at the second site. This shift in composition represents a decrease in range condition on a Clayey range site. Thus, results of this study did not show consistent benefits to atrazine use. However, there may be other indirect benefits from controlling Japanese brome, such as increased forage quality (perennials vs. annuals) or better livestock distribution (reduced area avoidance). These benefits would have to be substantial in order to make the use of atrazine economically justifiable in our situation.

\section{Literature Cited}

Arnold, W.E., and W.B. O'Neal. 1972. Japanese chess control in native pastures. North Central Weed Control Conference. Res. Rep. 29:13-15.

Dyksterhuis, E.J. 1949. Condition and management of range land based on quantitative ecology. J. Range Manage. 2:104-115.

Houston, W.R. 1977. Species susceptibility to atrazine herbicide on shortgrass range. J. Range Manage. 30:50-52.
Houston, W.R., and D.H. van der Sluijs. 1973. Increasing crude protein content of forage with atrazine on shortgrass range. U.S. Dep. Agr. Prod. Res. Rep. 153. 10 p.

Houston, W.R., and D.H. van der Sluijs. 1975. S-Triazine herbicides combined with nitrogen fertilizer for increasing protein on shortgrass range. J. Range Manage. 28:372-376.

Hulbert, L.C. 1955. Ecological studies of Bromus tectorum and other annual bromegrasses. Ecol. Monogr. 25:181-213.

Hyder, D.N., W.R. Houston, and J.B. Burwell. 1976. Drought resistance of blue grama as affected by atrazine and $\mathbf{N}$ fertilizer. J. Range Manage. 29:214-216.

Kay, B.L. 1971. Atrazine and simazine incrcase yicld and quality of range forage. Weed Sci. 19:370-372.

Lewis, J.K., M. Haferkamp, J.R. Lacey, R. Gibbens, J. Herndon and L. Blome. 1975. Effect of range condition on steer gains. South Dakota Agr. Exp. Sta. Anim. Sci. Series 75-4. 12 p.

Morrow, L.A., C.R. Fenster, and M.K. McCarty. 1977. Control of downy brome on Nebraska rangeland. J. Range Manage. 30:293-296.

Steele, R.G.D., and J.H. Torrie. 1960. Principles and Procedures of Statistics. McGraw-Hill, New York. 481 p.

U.S. Dep. Agr. 1977. Western South Dakota technical guide. U.S. Dep. Agr. Soil Conserv. Serv. Huron. 